\title{
Penerapan Konsep Going Concern Bagi Perseroan Terbatas Yang Telah Dinyatakan Pailit
}

\section{Nyoman Yatna Dwipayana Genta ${ }^{1}$, I Nyoman Suyatna ${ }^{2}$}

\author{
${ }^{1}$ Program Studi Magister (S2) Kenotariatan Fakultas Hukum Universitas Udayana, E-mail: \\ nyomangenta@gmail.com \\ ${ }^{2}$ Fakultas Hukum Universitas Udayana, E-mail: nyoman_doblar@yahoo.com
}

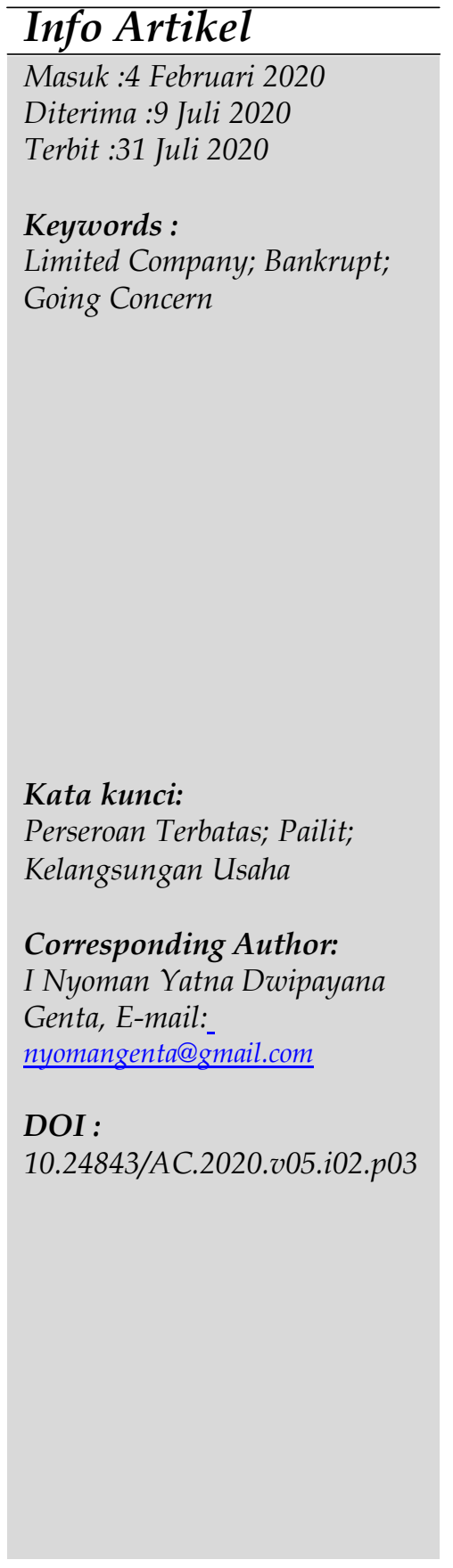

\begin{abstract}
In this research, will be discuss how the application of the concept of going concern in the UUK-PKPU and how the impact of the application of going concern in the settlement of a limited company that has been declared bankrupt. The writing method used is normative juridical by using the statutory approach and conceptual approach. Regarding the form of going concern application in UUK-PKPU, it is reflected in the provisions of Article 179 paragraph (1) which is in line with the mandates of Article 25 of UUK-PKPU. By doing this going concern does not necessarily delay the implementation of liquidation of state assets, assets that are not part of or can support the going concern still will be liquidated based on applicable regulations. It can be concluded that with the enactment of going concern is an effort to increase the value of bankrupt assets which are expected to be used to pay off the remaining bankrupt debts. As well as the implementation of going concern is an effort that does not preclude the process of liquidation of bankrupt assets as long as the liquidated assets do not obstruct the going concern process.
\end{abstract}

\begin{tabular}{l}
\hline Abstrak \\
\hline Dalam penelitian ini akan membahas mengenai bagaimana \\
bentuk penerapan konsep going concern di dalam UUK-PKPU \\
dan bagaimanakah dampak penerapan going concern dalam \\
penyelesaian perseroan terbatas yang telah dinyatakan pailit. \\
Metode penulisan yang digunakan adalah yuridis normatif \\
dengan menggunakan pendekatan perundang-undangan dan \\
pendekatan konseptual. Mengenai bentuk penerapan going \\
concern dalam UUK-PKPU tercermin di dalam ketentuan Pasal \\
179 ayat (1) yang mana ketentuan tersebut sejalan dengan \\
amanat Pasal 25 UUK-PKPU. Dengan dilakukannya going \\
concern ini tidak serta merta menunda pelaksanaan likuidasi \\
terhadap harta kekayaan persero, terhadap harta yang tidak \\
menjadi bagian atau dapat mendukung kerberlangsungan going \\
concern akan tetap dilikuidasi berdasarkan aturan yang berlaku. \\
Dapat disimpulkan bahwa dengan diberlakukannya going \\
concern merupakan salah satu usaha untuk meningkatkan nilai \\
dari harta kekayaan persero pailit yang diharapkan dapat \\
digunakan untuk melunasi sisa utang persero pailit. Serta \\
dengan diberlakukannya going concern ini merupakan upaya \\
yang tidak menghalangi proses likuidasi terhadap harta \\
kekayaan persero pailit selama harta yang dilikuidasi tidak
\end{tabular}




\section{Pendahuluan}

Melakukan kegiatan bisnis dengan bentuk perseroan terbatas (yang selanjutnya disebut PT) memiliki suatu keunggulan sehingga menjadi daya tarik bagi pelaku bisnis. Daya tarik bentuk usaha dengan menggunakan PT yakni disebabkan kekayaan suatu perusahaan akan dipisahkan atas kekayaan pribadi yang dimiliki oleh pelaku usahanya. Selain itu, kegiatan bisnis dengan bentuk PT juga memiliki peran bagi perkembangan perekonomian suatu negara. Hal ini disebabkan karena usaha dengan berbentuk PT memberikan peluang bagi pelaku usaha dari negara lain untuk melakukan bisnis di Indonesia. Kontribusi yang diberikan melalui kegiatan bisnis tersebut dapat dilihat dari adanya penanaman modal asing (PMA).

Naamloze Vennootschaap atau Bahasa Indonesia menyebutnya dengan PT yang merupakan suatu bentuk persekutuan yang mana menjalankan usahanya yang mana sahamnya terpisah dari modal, yang mana setiap pemilik memiliki bagian berdasarkan jumlah saham yang dimilikinya. Dalam UU PT menjelaskan PT yakni sebagai, “badan hukum yang merupakan persekutuan modal, didirikan berdasarkan perjanjian, melakukan kegiatan usaha dengan modal dasar yang seluruhnya terbagi dalam saham dan memenuhi persyaratan yang ditetapkan dalam Undang-Undang ini serta peraturan perlakasaannya." PT dalam menjalankan suatu bentuk kegiatan usaha tentu saja memerlukan adanya modal sebagai pendukung kelangsungan usaha. Modal yang dimiliki PT dapat dilihat di anggaran dasar (AD).

Pada prinsipnya PT sebagai badan hukum dalam menjalankan usahanya memiliki hakhak serta kewajiban-kewajiban yang harus dilaksanakan dalam melakukan perbuatan hukum, hal ini dianalogikan selayaknya manusia. Hal ini dapat dilihat bahwa PT memiliki kekayaan tersendiri, selain itu PT dimungkinkan untuk mengajukan gugatan maupun digugat ke pengadilan. Keadaan dimana PT sebagai badan hukum memiliki status, kedudukan, serta kewenangan dalam perbuatan hukum selayaknya manusia, maka PT dapat disebut sebagai artificial person. Sebagaimana seperti yang telah disebutkan sebelumnya, dalam menjalankan usaha PT tentu memerlukan modal.

Dalam keadaan dimana PT mengalami kekurangan modal, maka PT dalam melakukan kegiatan utang piutang guna memenuhi kebutuhannya akan modal. Melalui kegiatan utang piutang ini diharapkan dapat memberikan tambahan modal yang dapat membantu mengembangkan suatu usaha. Dalam pelaksanaannya tidak jarang meskipun suatu PT telah memiliki modal yang cukup, namun manajemen perseroan yang tidak baik maka perseroan tersebut memungkinkan mengalami kemunduran yang pada akhirnya mengalami kegagalan. Kegagalan bagi sebuah PT yang modalnya berasal dari kegiatan utang piutang, memungkin untuk memposisikan PT tersebut dalam kondisi pailit. Pailit adalah suatu keadaan dimana seseorang telah berhenti dan tidak memiliki kemampuan lagi guna memenuhi prestasinya dalam pelunasan utangnya berdasarkan putusan Hakim atau Pengadilan Niaga. ${ }^{1}$

\footnotetext{
${ }^{1}$ Isfardiyana, S. H. (2016). Sita Umum Kepailitan Mendahului Sita Pidana dalam Pemberesan Harta Pailit. Padjadjaran Journal of Law, 3(3), 628-650.
} 
Ketentuan tentang kepailitan yang saat ini berlaku di Indonesia diatur di dalam UUKPKPU. Melalui produk hukum ini dibuat dengan harapan agar dapat dipergunakan guna menjadi jalan keluar untuk debitor pailit yang sedang menghadapi kesulitan keuangan (financial distress) untuk tidak merasa tertekan karena selalu ditagih membayar oleh kreditornya dan di sisi lain melalui hukum ini juga akan memberikan akses dan kesempatan kepada kreditor untuk dapat memperoleh pelunasan melalui aset-aset yang dimiliki oleh debitor meski nilai aset dan utang tidak sama. ${ }^{2}$ Diciptakannya hukum kepailitan ini merupakan bertujuan untuk membagi harta debitor kepada pada kreditornya sebagai jalan pelunasan utang yang pengurusannya diselesaikan oleh kurator berdasarkan penunjukkan dengan pengawasan hakim pengawas setelah adanya putusan pailit diucapkan. ${ }^{3}$

Suatu bentuk jalan secara hukum untuk dapat ditempuh oleh kreditor agar dapat memperoleh haknya mendapatkan pelunasan dapat dilakukan melalui proses kepailitan dengan menggunakan upaya secara paksa berdasarkan putusan kepailitan yang diputus oleh pengadilan niaga. Baik perseroangan maupun badan hukum hanya akan dapat dikatakan pailit ketika terhadap orang maupun badan hukum tersebut telah diputus pailit melalui putusan pailit yang diputus oleh hakim pengadilan niaga. ${ }^{4}$ Akibat hukum yang timbul ketika diputus pailit yakni atas harta kekayaan yang dimiliki akan diletakkan pada status sita umum (automatic stay) yang menyebabkan seorang debitor yang telah dinyatakan pailit tidak akan lagi memiliki hak mengenai penguasaan dan menggunakan harta kekayaannya.

Sejak suatu PT dinyatakan dalam keadaan pailit, maka pada saat itu seluruh harta kekayaan persero akan berada di bawah sita umum sehingga seluruh kekayaan tersebut akan beralih statusnya menjadi harta pailit. Keadaan ini akan menyebabkan harta pailit tersebut dibekukan atau dapat dikatakan dalam keadaan stay untuk jangka waktu tertentu dan diawasi serta diurus oleh kurator. Berbeda dengan kepailitan yang dialami oleh perorangan, harta perseroan terpisah dengan harta pribadi milik para pengurus maupun pemegang saham dari PT berdasarkan prinsip separate legal entity dan limited liability dari para pemegang saham persero. Sehingga kepailitan persero terbatas hanya akan memiliki akibat secara langsung terhadap harta perseroan yang terdaftar atas nama perseroan maupun piutang perseroan.

Berdasarkan definisi kepailitan menurut Pasal 1 ayat (1) UUK-PKPU, keberadaan kurator dalam kepailitan persero menimbulkan kesan bahwa perseroan yang dinyatakan pailit telah bubar seketika dan kurator akan bertindak selaku likuidator untuk melakukan pemberesan. Namun pada kenyataannya, selama keadaan insolven belum terjadi atau tidak adanya pencabutan kepailitan, maka pernyataan pailit terhadap persero belum dapat mengakibatkan perseroan menjadi bubar. Hal ini sesuai menurut ketentuan Pasal 142 ayat (1) huruf e UU PT yang menentukan mengenai kapan suatu perseroan dinyatakan bubar.

Bagi perseroan yang dinyatakan pailit namun belum berstatus insolven, maka secara juridis belum dapat dikatakan bubar dan oleh karena itu keadaan pailit tidak akan

\footnotetext{
${ }^{2}$ Retnaningsih, S. (2018). Perlindungan Hukum Terhadap Debitor Pailit Individu Dalam Penyelesaian Perkara Kepailitan di Indonesia. Jurnal Hukum Acara Perdata, 3(1), 1-16.

${ }^{3}$ Kartoningrat, R. B., \& Andayani, I. (2018). Mediasi Sebagai Alternatif dalam Pengurusan dan Pemberesan Harta Pailit oleh Kurator Kepailitan. Halu Oleo Law Review, 2(1), 291-305.

${ }^{4}$ Makmur, S. (2018). Kepastian Hukum Kepailitan Bagi Kreditur dan Debitur Pada Pengadilan Niaga Indonesia. Mizan: Journal of Islamic Law, 4(2).
} 
menghalangi kelangsungan usaha atau dapat disebut going concern. Berdasarkan Pasal 104 ayat (1) yang memberikan adanya grace period bagi kurator untuk mengajukan usul melanjutkan badan usaha perseroan pailit sejak hari pertama perseroan dinyatakan pailit. Berdasarkan perpektif UUK-PKPU, keberlangsungan suatu usaha perseroan tetap masih dapat dilanjutkan meski telah dinyatakan insolven, sedangkan berdasarkan UU PT, perseroan yang sudah dinyatakan insolven maka akan bubar demi hukum. Berdasarkan penjabarkan tersebut, maka terdapat dua rumusan masalah yang akan dibahas dalam penulisan ini yakni pertama mengenai bagaimana bentuk penerapan konsep going concern di dalam Undang-Undang Nomor 37 Tahun 2004 tentang Kepailitan dan Penundaan Kewajiban Pembayaran Utang. Kedua, bagaimanakah dampak penerapan going concern dalam penyelesaian perseroan terbatas yang telah dinyatakan pailit?

\section{Metode Penelitian}

Suatu penelitian ilmiah tentu menggunakan suatu metode untuk dapat melakukan penelitian. Metode penelitian sebagai suatu bentuk prosedur yang menjadi pedoman dalam mendapatkan pengetahuan dibidang keilmuan. Metode penelitian ini bertujuan agar suatu penelitian dapat memenuhi kriteria yang menjadi syarat dari suatu karya ilmiah. Secara garis besar, suatu penelitian hukum dapat ditinjau berdasarkan tujuan dari penelitian tersebut yakni penelitian hukum dengan metode penelitian normatif dan penelitian hukum dengan metode sosiologis (empiris). Penelitian suatu tulisan yang bersifat karya ilmiah ini akan menggunakan metode dengan jenis penelitian hukum yang dengan metode yuridis normatif, yang artinya dilakukan berdasarkan penelitian bahan kepustakaan seperti peraturan perundang-undangan, serta buku-buku yang memiliki kaitan dengan hukum, dan juga kamus serta ensiklopedi. ${ }^{5}$

Pendekatan dilakukan guna mempermudah bagi peneliti dalam hal memperoleh informasi berdasarkan berbagai aspek yang berbeda sehubungan dengan isu hukum yang coba diperoleh jawabannya. Adapaun pendekatan yang dapat digunakan terhadap penulisan karya ilmiah ini yakni pendekatan perundang-undangan dan pendekatan konseptual. Pendekatan perundang-undangan merupakan suatu pendekatan dengan menggunakan legislasi dan regulasi ${ }^{6}$, sedangkan pendekatan konseptual yakni pendekatan dengan menggunakan konstruksi konsep hukum.

Karya ilmiah ini juga didukung dengan menggunakan 3 (tiga) sumber bahan hukum yaitu bahan hukum primer, sekunder, serta tertier. Bahan hukum primer diwujudkan berupa asas serta kaidah hukum yang terkadung dalam Peraturan Dasar, Konvensi Ketatanegaraan, Peraturan Perundang-Undangan, hukum yang tidak tertulis, putusan pengadilan, serta Keputusan Tata Usaha Negara. Dalam bahan hukum yang bersifat sekunder terdiri atas buku-buku hukum yang mendukung, jurnal-jurnal hukum, serta kamus dan ensiklopedia hukum.7 Pada tahap pengumpulan bahan hukum diawali dengan melakukan suatu kegaiatan yang bersifat inventarisasi, yang mana pada tahap ini akan dilakukan dengan melakukan pengkoleksian dan juga melakukan pengurutan

\footnotetext{
5Soerjono Soekanto dan Sri Mamudji, 2009, Penelitian Hukum Normatif Suatu Tinjauan Singkat, Raja Grafindo Persada, Jakarta, h.13-14.

${ }^{6}$ Ibid, h. 137.

${ }^{7}$ Magister Kenotariatan Universitas Udayana, 2015, Buku Pedoman Pendidikan Program Studi Magister Kenotariatan Universitas Udayana, Denpasar 01-09-2015, h. 48.
} 
atas bahan hukum yang didapatkan agar dapat disusun menjadi suatu sistem dalam memperoleh informasi, sehingga akan mempermudah dalam penelurusan bahan hukum yang telah diperoleh.

Selanjutnya bahan hukum yang telah didapatkan akan dikumpulkan dengan studi dokumentasi, yang mana akan dilakukan pencatatan atas sumber bahan hukum yang diperoleh baik yang bersifat primer dan juga sekunder, yang mana selanjutkan akan dilakukan suatu kegiatan inventarisasi atas bahan hukum sehingga akan menjadi relevan dengan penelitian ini serta pencatatan yang dilakukan akan menggunakan sistem kartu. Setelah mendapatkan informasi yang dibutuhkan selanjutkan akan dilanjutkan dengan penelusuran dengan metode kepustakaan yang mana relevan dengan apa yang menjadi topik dalam penelitian ini yakni mengenai konsep going concern terhadap perseroan terbatas yang telah dinyatakan pailit. Agar dapat menkadi pendukung dalam penyelesaian penulisan karya ilmiah ini, maka akan dilakukan suatu studi kepustkaan (library research) guna mengkaji, dan juga mekakukan penelaahan serta menyusun literatur dan peraturan yang terkait, dan didukung dengan artikel dan tulisan ilmiah lainnya yang memiliki kaitan dengan rumusan masalah dalam penelitian ini.

\section{Hasil Dan Pembahasan}

\subsection{Bentuk Penerapan Konsep Going Concern Dalam Undang-Undang Nomor 37 Tahun 2004 tentang Kepailitan dan Penundaan Kewajiban Pembayaran Utang}

Going concern atau yang Bahasa Indonesia menyebutkan kelangsungan usaha adalah suatu asas yang dianut di dalam UUK-PKPU. Dapat dikatakan bahwa yang dimaksud sebagai going concern yakni badan usaha telah dianggap tidak memiliki kemampuan lagi untuk mempertahakan usahanya dalam kurun waktu yang relatif panjang dan tidak akan dilakukan likuidasi dalam kurun waktu yang panjang. ${ }^{8}$ Pada peraturan tersebut, usaha untuk melaksanakan asas ini didasarkan pada tujuan untuk meningkatkan nilai harta pailit. Pertimbangan utama dilakukannya going concern terhadap suatu persero yang sudah diputus pailit yakni bahwa menurut penilaian secara ekonomis (secara economic value) perusahaan yang telah pailit tersebut lebih baik dibandingkan dengan hanya menilai aset fisik dari perusahaan tersebut. Mengenai usul guna melanjutkan usaha debitor pailit yang dinilai masih dapat diusahakan going concern dapat diusulkan pada 2 (dua) fase, yakni pada fase dimana harta pailit belum berstatus insolven dan pada fase dimana harta pailit telah insolven.

Pada fase harta pailit belum berstatus insolven, maka tugas pengurusan dapat dimulai berdasarkan persetujuan dari para panita kreditor sementara (jika ada) atau mendapat izin dari hakim pengawas. Apabila telah mendapatkan izin, maka kurator sebagai pelaksana dapat meneruskan usaha debitor pailit meskipun mengenai putusan pailit dilakukan upaya hukum lain yakni kasasi atau sedang dalam tahap peninjauan kembali. Menurut ketentuan dalam Pasal 179 ayat (1) UUK-PKPU, seorang kurator diberikan kewenangan dalam menuntukan untuk melanjutkan kelangsungan usaha debitor pailit yang mana dianggap dapat memberikan peningkatan nilai terhadap harta pailit sesuai dengan prinsip yang terkandung di dalam Pasal 25 UUK-PKPU yang menegaskan bahwa semua bentuk perikatan yang dilaksanakan oleh debitor pailit dalam kurun

\footnotetext{
${ }^{8}$ Santosa, A. F., \& Wedari, L. K. (2007). Analisis Faktor-Faktor yang Mempengaruhi Kecenderungan Penerimaan Opini Audit Going Concern. Jurnal Fakultas Hukum UII, 11(2).
} 
waktu setelah adanya putusan pailit, maka terhadap perikatakan tersebut tidak dapat dilakukan suatu bentuk pembayaran dengan harta yang sudah dijadikan boedel, terkecuali atas perikatan tersebut akan mendatangkan keuntungan bagi harta tersebut.

Diajukannya usul oleh kurator untuk melaksanakan going concern pada suatu persero yang telah pailit yang diajukan sebelum harta pailit tersebut insolven, hal ini mengindikasikan bahwa adanya peluang besar untuk meningkatkan nilai dari harta pailit tersebut. Usul yang diajukan ini hanya memerlukan izin yang diberikan oleh panitia kreditor sementara atau izin yang diberikan oleh hakim pengawas jika tidak ada yang diangkat sebagai panitia kreditor sementara. Pelaksanaan going concern akan dievaluasi pada saat harta pailit telah dinyatakan insolvensi. Baik pihak kurator maupun kreditor dapat mengusulkan kepada hakim pengawas mengenai usaha tersebut untuk dapat dihentikan karena dinilai kegiatan tersebut telah merugikan atau mengurangi dari nilai harta pailit.

Namun dalam hal kurator diberikan kewenangan untuk melaksanakan going concern, kurator tidak mengambil alih seluruh kewenangan dari organ persero itu sendiri, karena yang dapat menjalankan suatu persero hanya organ persero seperti direksi, komisaris, serta Rapat Umum Pemegang Saham (RUPS). Tugas pengampuan dari kurator pada suatu persero yang pailit memiliki sifat terbatas (limited custodian), yakni hanya sebatas pada pengurusan serta pemberesan harta perseroan pailit. Pernyataan pailit yang melekat pada suatu persero tidak memiliki sifat serta merta menempatkan direksi di bawah pengampuan dari kurator. Hal ini didasarkan pada direksi selaku pengurus perseroan tetap memiliki kewajiban dalam hal pengurusan perseroan sesuai dengan fiduciary duty dan duty of care sepanjang tidak menyangkut pengelolaan serta penyelesaian harta pailit.

Di dalam UUK-PKPU tidak mengatur mengenai kewenangan kurator yang dapat didelegasikan guna memberikan pengurusan serta pemberesan harta pailit kepada pihak lain yang tidak diberikan kewenangan oleh UUK-PKPU, termasuk dalam hal ini pengurusan dan pemberesan diberikan kepada dewan direksi perseroan. Apabila suatu perseroan mengalami kegagalan yang disebabkan oleh manajemen usaha yang kurang baik, maka berdasarkan Pasal 104 ayat (2) serta Pasal 115 ayat (1) UU PT terjadi perluasan tanggung jawab direksi dan komisaris perseroan guna membayar utang perseroan yang pailit akibat dari kelalaian mereka mengurus perseroan.

Pada fase dilakukan rapat pencocokan utang ataupun harta pailit telah dinyatakan insolven, maka pengajuan usaha going concern tetap dapat diusulkan oleh pihak kurator maupun kreditor. Hal ini diatur di dalam ketentuan Pasal 179 ayat (1) UUK-PKPU, namun tidak diatur secara tegas mengenai apakah usul untuk melakukan going concern ini diajukan oleh kreditor konkuren atau boleh oleh seluruh kreditor tanpa terkecuali. Pasal 179 ayat (1) UUK-PKPU menyebutkan bahwa, "jika dalam rapat pencocokan piutang tidak ditawarkan rencana perdamaian atau jika rencana perdamaian yang ditawarkan tidak diterima, kurator atau kreditor yang hadir dalam rapat dapat mengusulkan supaya perusahaan debitor pailit dilanjutkan". Mengingat bahwa kreditor separatis memiliki kedudukan diluar kepailitan debitor, maka yang paling berkepentingan dengan going concern ini adalah kreditor konkuren. Apabila merujuk pada ketentuan Pasal 180 ayat (1) UUK-PKPU, maka dapat dilihat bahwa going concern terhadap usaha debitor pailit diputuskan sepenuhnya oleh kreditor konkuren. 
Going concern terhadap usaha yang telah dinyatakan pailit diambil manakala perseroan tersebut tidak mengajukan proposal perdamaian hingga dilaksanakannya rapat pencocokan utang berakhir dan harta pailit dinyatakan insolven. Alternatif lain yang ditawarkan yakni usulan untuk melaksanakan going concern diajukan setelah pengadilan niaga menolak mengesahkan perdamaian. Bisa saja terjadi perseroan telah mengajukan proposal yang disetujui oleh kreditor, yang mana persetujuan tersebut mengindikasikan adanya suatu harapan untuk harta pailit agar terhindar dari keadaan insolven. Namun apabila pengadilan niaga memutuskan untuk menolak pengesahan perdamaian tersebut, maka sesuai dengan ketentuan Pasal 178 ayat (1) UUK-PKPU maka harta pailit akan tetap berstatus insolven.

Keadaan insolven terhadap harta pailit persero tidak akan menghalangi kurator atau kreditor untuk dapat mengusulkan agar usaha perseroan pailit dapat dilanjutkan. Waktu yang diberikan untuk dapat mengusulkan status going concern setelah harta pailit dinyatakan insolven sangat terbatas, yakni harus diajukan dalam tempo waktu 8 (delapan) hari setelah adanya putusan penolakan pengesahan pengajuan perdamaian diucapkan oleh hakim pengadilan niaga. Apabila lewat dari jangka waktu tersebut, maka usul untuk melanjutkan usaha tidak dapat lagi diproses dalam rapat kreditor dan kurator dapat melikuidasi seluruh harta pailit. Hal ini sesuai berdasarkan ketentuan Pasal 181 ayat (1) UUK-PKPU yang menentukan bahwa, "apabila dalam jangka waktu 8 (delapan) hari setelah putusan penolakan pengesahan perdamaian memperoleh kekuatan hukum tetap, kurator atau kreditor mengajukan usul kepada hakim pengawas untuk melanjutkan perusahaan debitor pailit, hakim pengawas wajib mengadakan suatu rapat paling lambat 14 (empat belas) hari setelah usul disampaikan kepada hakim pengawas".

Keputusan untuk meneruskan suatu usaha perseroan yang sudah dinyatakan pailit setelah harta pailitnya tersebut berada pada posisi insolven merupakan kewenangan para kreditor konkuren untuk memutuskannya. Keputusan ini harus dibicarakan dalam rapat kreditor yang diselenggarakan secara khusus untuk itu oleh kurator dengan mengundang seluruh kreditornya yang telah terdaftar dengan panggilan umum di surat kabar. Usaha perseroan pailit dapat diajukan apabila kreditor konkuren yang dapat mewakili lebih dari $1 / 2$ (satu per dua) dari keseluruhan piutang yang telah diakui serta diterima dengan sementara memberi persetujuan.

\subsection{Dampak Penerapan Going Concern Dalam Penyelesaian Perseroan Terbatas yang Telah Dinyatakan Pailit}

Meskipun status suatu usaha perseroan kepailitan dalam keadaan going concern tidak akan menghalangi atau menunda likuidasi dari harta perseroan tersebut. Likuidasi yang dilaksanakan terhadap harta perseroan pailit tetap akan dilaksanakan, namun hal ini akan dibatasi terhadap harta yang sedang dilakukan kelangsungan usahanya serta terbatas juga terhadap harta-harta pailit persero yang dapat digunakan untuk mendukung kelangsungan usaha. Dengan kata lain, dengan dilaksanakannya going concern maka terhadap harta yang sedang dilakukannya proses tersebut serta harta pendukung kelangsungan usaha akan ditahan sementara dan tidak dilakukan penjualan atas harta tersebut. Namun apabila para kreditor konkuren tidak setuju akan keputusan untuk melanjutkan kelangsungan usaha atau tidak setuju going concern ini dilaksanakan, maka terhadap usaha akan berlaku secara efektif ketentuan Pasal 184 ayat (1) huruf a dan b UUK-PKPU yakni, “dengan tetap memperhatikan ketentuan Pasal 15 ayat (1), 
kurator harus memulai pemberesan dan menjual semua harta pailit tanpa perlu memperoleh persetujuan atau bantuan debitor pailit: (a) usul untuk mengurus perusahaan debitor tidak diajukan dalam jangka waktu sebagaimana diatur dalam undang-undang ini, atau usul tersebut telah diajukan tetapi ditolak; atau (b) pengurus terhadap perusahaan debitor dihentikan". Maka dengan kata lain perseroan secara definitif telah bubar dan harta pailit harus segera dilikuidasi oleh kurator tanpa perlu mendapat bantuan atau persetujuan dari organ perseroan pailit.

Proses going concern yang dilakukan terhadap perseroan pailit berdasarkan kesepakatan dari kreditor konkuren dapat dievaluasi. Apabila setelah diusahakan untuk melangsungkan usaha terhadap harta pailit persero mengalami penyusutan nilai yang disebabkan karena untuk membiayai operasional perseroan serta karenanya tidak memberikan nilai terhadap harta pailit tersebut, maka terhadap kelangsungan usaha yang dilakukan harus dihentikan. Permohonan untuk menghentikan kelangsungan usaha tersebut didasari pada keadaan dimana kelangsungan usaha debitor pailit ternyata tidak berjalan sesuai dengan ketentuan Pasal 25 UUK-PKPU. Apabila kelangsungan usaha terhadap perseroan pailit tersebut telah dihentikan berdasarkan penetapan hakim pengawas, maka kurator memiliki kewenangan untuk melikuidasi keseluruhan aset perseroan pailit tanpa bantuan atau seizin dari organ perseroan pailit. Di sisi lain, apabila ketentuan dalam Pasal 184 ayat (1) UUK-PKPU ini dihubungkan dengan ketentuan yang terkandung dalam Pasal 142 ayat (1) huruf e dan f UU PT yang menentukan mengenai kapan suatu perseroan dinyatakan bubar, maka keadaan insolven mengakibatkan perseroan bubar dan harus dilikuidasi. Sehingga kesempatan untuk melakukan going concern perseroan terkesan tidak sejalan dengan ketentuan UU PT. Meskipun telah ditentukan demikian dalam UU PT, untuk penyelesaian perkara kepailitan suatu perseroan atau badan hukum lainnya tetap harus tunduk pada ketentuan UUK-PKPU, maka mengenai prosedur pengurusan serta pemberesan harta perseroan pailit tetap tunduk pada UUK-PKPU.

\section{Kesimpulan}

Berdasarkan hasil dari pemaparan sebelumnya, maka dapat disimpulkan bahwa Going concern adalah suatu asas yang termuat dalam UUK-PKPU yang mana tercermin di dalam ketentuan Pasal 179 ayat (1) UUK-PKPU. Keberlakuan asas ini merupakan salah satu upaya yang dilakukan terhadap harta pailit yang dianggap memungkinkan akan memiliki nilai lebih apabila dilanjutkan kelangsungan usaha persero tersebut. Namun keputusan untuk melakukan going concern ini harus berdasarkan keputusan dari kreditor konkuren dan disetujui oleh hakim pengawas. Dengan dilakukannya kelangsungan usaha, tidak akan menyebabkan berhentinya proses likuidasi atas harta persero. Terhadap harta pailit yang dianggap masih memiliki potensi untuk ditingkatkan nilainya, maka terhadap harta tersebut akan ditangguhkan proses likuidasinya dan dijalankan kelangsungan usahanya. Apabila setelah dijalankan tetapi tidak memperlihatkan adanya peningkatan nilai dan terjadi sebaliknya, maka kelangsungan usaha akan dihentikan dan kemudian dilanjutkan untuk dilikuidasi sebagai cara penyelesaian sisa piutang persero.

\section{DAFTAR PUSTAKA}

\section{Buku :}


Soerjono Soekanto dan Sri Mamudji, 2009, Penelitian Hukum Normatif Suatu Tinjauan Singkat, Raja Grafindo Persada, Jakarta.

Magister Kenotariatan Universitas Udayana, 2015, Buku Pedoman Pendidikan Program Studi Magister Kenotariatan Universitas Udayana, Denpasar 01-09-2015.

\section{Jurnal Ilmiah :}

Isfardiyana, S. H. (2016). Sita Umum Kepailitan Mendahului Sita Pidana dalam Pemberesan Harta Pailit. Padjadjaran Journal of Law, 3(3), 628-650.

Retnaningsih, S. (2018). Perlindungan Hukum Terhadap Debitor Pailit Individu Dalam Penyelesaian Perkara Kepailitan di Indonesia. Jurnal Hukum Acara Perdata, 3(1), 1-16.

Kartoningrat, R. B., \& Andayani, I. (2018). Mediasi Sebagai Alternatif dalam Pengurusan dan Pemberesan Harta Pailit oleh Kurator Kepailitan. Halu Oleo Law Review, 2(1), 291-305.

Makmur, S. (2018). Kepastian Hukum Kepailitan Bagi Kreditur dan Debitur Pada Pengadilan Niaga Indonesia. Mizan: Journal of Islamic Law, 4(2).

Santosa, A. F., \& Wedari, L. K. (2007). Analisis Faktor-Faktor yang Mempengaruhi Kecenderungan Penerimaan Opini Audit Going Concern. Jurnal Fakultas Hukum UII, 11(2). 